\title{
Robotic Technology for Figural Creativity Enhancement: Case Study on Elementary School
}

\author{
Billy Hendrik ${ }^{1}$, Nazlena Mohamad $\mathrm{Ali}^{2 *}$, Norshita Mat Nayan ${ }^{3}$ \\ Dept. Institute of Visual Informatics, Universiti Kebangsaan Malaysia, Bangi, Malaysia ${ }^{1,2,3}$ \\ Dept. Faculty of Computer Science, Universitas Putra Indonesia "YPTK" Padang, Padang, Indonesia ${ }^{1}$
}

\begin{abstract}
Robotic technology is a field that is in great demand today and it is very useful to human life, especially in the aspect of education. It would help students to be more active in the learning process. Creativity can be stimulating with the use of robotic technology. One kind of creativity is Figural Creativity (FC). This study investigated the effect of Robotic Technology as a learning tool to improve the FC skills of students. Forty (40) elementary school students aged 10-11 years, were the participants in this study. Students' creativity skills were measured from the Figural Creativity Test (TKF). This test was carried out before the intervention (pre-test) and after the intervention program (post-test). In the intervention program, students were given some education about robotic technology. To analyze the test results, we made use of the Statistical Service Products and Solutions package. The findings showed that the level of creativity in students with the $\mathrm{K13}$ curriculum improved better, the FC scores of students in $\mathrm{K}-13$ Curriculum were improved up to $23 \%$ with sig. 2 -tailed $=.000, p<.05$ and the FC scores of the KTSP curriculum only improved only by $1.7 \%$ with sig.2-tailed value $=.572, p>.05$. Thus, robotic technology learning is more effective in improving the FC of students with the K13 curriculum. Based on the result, we make a recommendation to the Ministry of Education that robotic technology is applied as an educational tool in the educational sectors.
\end{abstract}

Keywords-Robotic technology; figural creativity; curriculum; TKF; education; KTSP; K-13

\section{INTRODUCTION}

Changes in the education sector have become a favorite topic for analysis in the Revolution Industry 4.0 era. Inevitably this change must be made to prepare the creative community to compete with other countries, because creativity is considered as a precious asset for solving problems and achieving sustainable development [1]. Changing in education systems would not be separated from changes of curriculum, learning methods and learning tools; In Indonesia, The Ministry of National Education has made changes to the curriculum several times, such as that of the KTSP (unit lesson-based curriculum) and K13 (character-based curriculum); these changes are aimed at developing the quality of education in this country [2]. Implementation of an education system based on curriculum K13 is expected to produce students who have creative and innovative skills [3]. However, in practice there may be some obstacles to the development of creativity, which might still not be optimal. According to Billy et.al (2018), there is no significant difference between the figural creativity level of students in KTSP curriculum with the figural creativity level of students in K13 curriculum; even the curriculum of KTSP influences student's figural creativity more [4]. In order for the

\footnotetext{
*Corresponding Author.
}

objectives of the K13 curriculum to be achieved, it is necessary that there is improvement or development in its implementation.

To prepare children who will be ready to work in a world dominated by technology, we must develop the human creative spirit from the children as well as through technology. One of such technology that is growing today is robotics. A robot is a machine that can be programmed and reprogrammed to do certain tasks and usually consists of a manipulator such as a claw, hand, or tool attached to a mobile body or a stationary platform [5]. Robotic Technology on education will have a positive impact. Robotics offers a way to teach young children about the types of sensors and electronics they encounter in their daily life via a hands-on and engaging way. Teaching foundational programming concepts, along with robotics makes it possible to introduce children to important ideas that informs the design of many of the everyday objects they interact with [6].

Studies in the field of robotics have reported that robotics have a potential impact on students' learning in different subject areas (Physics, Mathematics, Engineering, Informatics and more) and on their personal development including cognitive, meta-cognitive and social skills, such as: research skills, creative thinking, decision making, problem solving, communication and team working skills, all of them being essential skills necessary in the workplace of the 21st century [7]. Educational robotics has emerged as a unique learning tool that can offer hands-on, fun activities in an attractive learning environment, feeding students' interest and curiosity. Robotic as a learning tool have the potential to positively contribute to successful learning [8]. Robot-based classes were found to increase creativity in an effective way, and all the sub-elements of creativity (fluency, originality, openness, and susceptibility) scored significantly higher in a post-verification test than the pre-verification test [9]. Creativity is the capacity to create, to produce new things, it is the capacity of the human brain to reach new conclusions and ideas as well as to solve problems in an original fashion [10]; another opinion "Creative thinking" is an original cognitive ability and problem solving process which enables individuals to use their intelligence in a way that is unique and directed toward coming up with a product [11]. Thus, Creative thinking skills is one of the capabilities required to solve various problems [12]. Creativity is increasingly recognized as a valuable asset for individuals in their daily problem solving and their professional careers, which contributes to personal and societal development [1], and being creative is a universal human attribute [13]. 
Furthermore, examined the use of a science and technology curriculum based on robotics to increase the achievement scores of youth ages 9-11 in an after-school program. The results revealed that youth in the robotics intervention had a significant increase in their mean scores on the post-test and that the control group had no significant change in scores from the pre-test to the post-test [7]. If we talk about innovation, of course, it will be related to creativity. Innovation is the implantation of creative inspiration. Innovation and creativity in the workplace have become increasingly important determinants of organizational performance, success, and longer-term survival [14], [15], [16]. However, the representation of creative abilities would have both local as well as global cultural influences [13]. Creativity is important to all businesses, whether they provide food, entertainment, transportation, or educational materials. It is essential to incorporate responsibility to the existence of any organization. Companies must be creative in order to compete in the marketplace and to continue developing products for a changing global society.

Although many studies have been carried out on the effect of robotics technology for creativity skills, nevertheless more studies still need to be conducted, especially with regards to the analysis of the application of robotic technology in different curricula and in the aspect of measuring the effects of robotics technology on creativity skills with standardized measuring instruments.

The goal of this study was to investigate the effect of Robotic Technology to improve the figural creativity skills of elementary school students who have different curricula. The results of this study may provide some vital suggestions to the educational sectors. This paper is divided into several sections. Section 2 discussed the materials and methods in carrying out the user experiment, followed by the results and discussion section.

\section{MATERIAL AND METHODS}

In this sub-chapter, we will explain the material and methods used in this study, such as participant, instrument, and procedure.

\section{A. Participant}

Participants in this study are elementary school students; with ages ranging from 10 to 11 years old, because development of creativity at this age is around 50\%-70\% [17], [18], [19], and at this age children are in the concrete operational stage, also in this stage the children has the ability to think rationally, imaginative, and can explore more objects or situation to solve problems. The participants were 40 students $(\mathrm{N}=40)$ from elementary schools with different curriculum in Sumatera Barat-Indonesia, KTSP curriculum and K13 curriculum. The students were selected by random sampling technique.

Total participants in the KTSP curriculum were 20 students (50\%), and the total participants in the K-13 curriculum were 20 students $(50 \%)$. The participant's mentioned was shortened to team A and team B as shown in Table I.

\section{B. Instrument}

Figural creativity of the students was measured by the Figural Creativity Test (TKF).Regarding the measurement of creativity, the most widely used test is the figural creativity test developed by Torrance known as TTCT (Torrance Tests of Creative Thinking) in the form of tests completing the picture (the drawing completions test) which is named the Wartegg test [20]. Other studies that also used TKF as a measure used it for the purpose of increasing the creativity of students through the implementations of $5 \mathrm{E}$ Learning Cycle with an Interrelationship Diagram for the students of X-8 class SMA Negeri 3 Surakarta school years 2012/2013 [21].

The creativity measured in TKF has an understanding as to the ability to form new combinations of given elements reflected in the fluency, flexibility, originality, and elaboration. Figural creativity scoring is comprised of four components: originality, fluency, flexibility, and elaboration [22], [23], [24]. The first element is originality, which implies that someone is able to produce an idea that is different from most people in the group. The answer is stated as original if the student is able to bring up a response that is included in $10 \%$ of the population, with a criteria such as the answer given by $10 \%$ or more of the subject is given a score of 0 . If the answer is given by $5-9 \%$ of the subjects, then it would be given a score of 1 . If the answer was given by $2-4 \%$ of subjects, then it would be assigned a score of 2 . If the answer is given by less than $2 \%$ of the subjects, then it would be given a score 3 . Answers that are not included in the list of originalities, were given a score of 3 . The second element is fluency, which deals with measuring how a person is able to think and come up with ideas quickly, precisely, and varies with a large quantity because the number of responses determines the score ( 1 point per idea). The third element is flexibility, which is the ability a person has to be able to provide ideas from different points of view or activities, the score is the category idea ( 1 point per category). The fourth element is the elaboration, this is a way that a person has to develop, detailing and complete an idea or ideas $(1,2$ or 3 points depending on the number of additional details drawn) [26]. The total score will be translated to a stan [25].

\section{Procedure}

In this study, in order to analyze the influence of robotics technology on creativity, we performed pre-test and post-test on elementary school students.

\section{Pre-Test}

Pre-Figural Creativity Test was performed on team A and team $\mathrm{B}$ in order to determine the level of figural creativity of the students before the intervention.

TABLE. I. DEMOGRAPHY TABLE OF PARTICIPANT

\begin{tabular}{|l|l|l|l|}
\hline Team & Curriculum & Total & Percentage (\%) \\
\hline A & KTSP & 20 & $50 \%$ \\
\hline B & K-13 & 20 & $50 \%$ \\
\hline
\end{tabular}


The pencil and paper tests were completed individually in a group administered session. The figural creativity test is made up of activities. The students are presented with a circular pattern (Fig. 1), and were asked to create an image which varies as much as possible and within 10 minutes it should have been determined using a circular pattern that has been given (Fig. 2); thus based on the images that have been made, the students were asked to provide the title of each image [26].

The total score is then being translated to the standard value and then the number of raw values becomes the creative quotient score, the creative quotient score also is being translated into four levels with intervals; Superior, High average, Average and Low Average [25]. The score for each creative quotient level can be seen in Table II.

\section{E. Intervention of Robotic Technology}

Robotic Technology intervention aims to increase the level of figural creativity in students, with the hope that the score of post-tests from students can increase. This section describes the activities that have been developed with children around the subject of robotics technology. The students from team A and team B got the intervention of robotic technology, this intervention consist of 7 meetings (see Table III).

Task 1. The robotics technology lessons consist of an introduction to the materials of the robotics technology via an audio-visual media, these activities give deeper knowledge about robotics technology. The students were introduced to several types of robots, such as robot with wheels, robot with legs, robot like a human. The next explanation was about the mechanical aspects of robots, sensor systems, microcontrollers, and actuators. Also, these explanations were being accompanied by experiment tools. The activity is shown in Fig. 3.

\section{StartIng Shapes}

Use

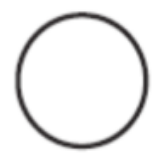

Fig. 1. Sample of Circular Pattern.

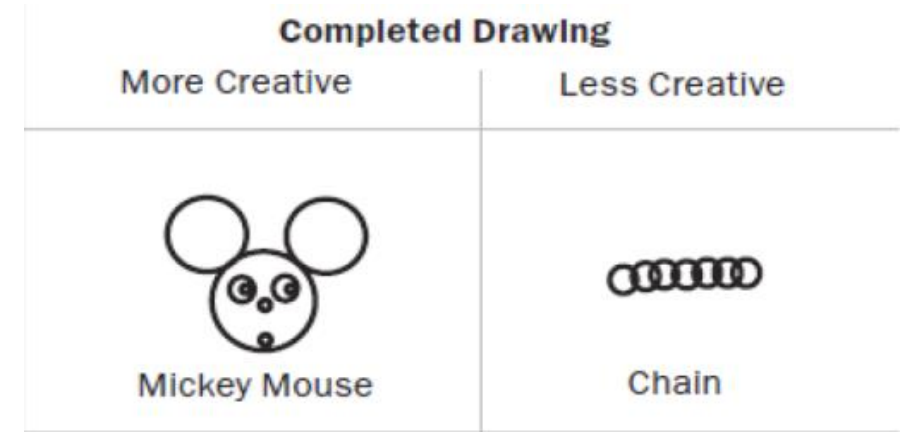

Fig. 2. Sample of Circular Pattern Answer Developed by Ellis Paul.
TABLE. II. LEVEL CREATIVE QUOTIENT

\begin{tabular}{|l|l|}
\hline Level & Score \\
\hline Superior & $>=120$ \\
\hline High Average & $111-119$ \\
\hline Average & $91-110$ \\
\hline Low Average & $80-90$ \\
\hline
\end{tabular}

TABLE. III. WEEKLY ROBOTICS TECHNOLOGY LESSON SCHEDULE

\begin{tabular}{|c|c|c|c|c|}
\hline Lesson & $\begin{array}{l}\text { Robotics } \\
\text { Technology } \\
\text { Lesson }\end{array}$ & Media & Purpose & Duration \\
\hline $\begin{array}{l}\text { Task } 1 \text { - } \\
\text { First } \\
\text { Lesson }\end{array}$ & $\begin{array}{l}\text { Introduction } \\
\text { and the } \\
\text { materials of } \\
\text { the robotics } \\
\text { technology }\end{array}$ & $\begin{array}{l}\text { Audio, } \\
\text { video }\end{array}$ & $\begin{array}{l}\text { Visualization and } \\
\text { imagination give } \\
\text { stimulation for fluency }\end{array}$ & 2h. $15 \mathrm{~min}$ \\
\hline $\begin{array}{l}\text { Task 2 - } \\
\text { Second } \\
\text { Lesson }\end{array}$ & $\begin{array}{l}\text { The robot } \\
\text { development } \\
\text { project using } \\
\text { arm robot }\end{array}$ & $\begin{array}{l}\text { Audio, } \\
\text { video, } \\
\text { robot, } \\
\text { Module }\end{array}$ & $\begin{array}{l}\text { Visualization, } \\
\text { imagination, diverse } \\
\text { classification give } \\
\text { stimulation for } \\
\text { fluency, flexibility } \\
\text { (Module), elaboration } \\
\text { (Module) }\end{array}$ & 2h. $30 \mathrm{~min}$ \\
\hline $\begin{array}{l}\text { Task } 3 \text { - } \\
\text { Third } \\
\text { Lesson }\end{array}$ & $\begin{array}{l}\text { The robot } \\
\text { development } \\
\text { project using } \\
\text { mobile robot }\end{array}$ & $\begin{array}{l}\text { Audio, } \\
\text { video, } \\
\text { robot, } \\
\text { Module }\end{array}$ & $\begin{array}{l}\text { Visualization, } \\
\text { imagination, making } \\
\text { stories, negation, } \\
\text { modifying give } \\
\text { stimulation for } \\
\text { fluency, flexibility, }\end{array}$ & 3h. $10 \mathrm{~min}$ \\
\hline $\begin{array}{l}\text { Task } 4 \text { - } \\
\text { Fourth } \\
\text { Lesson }\end{array}$ & $\begin{array}{l}\text { The robot } \\
\text { development } \\
\text { project using } \\
\text { drone }\end{array}$ & $\begin{array}{l}\text { Audio, } \\
\text { video, } \\
\text { robot, } \\
\text { Module }\end{array}$ & $\begin{array}{l}\text { Visualization, } \\
\text { imagination, negation } \\
\text { give stimulation for } \\
\text { fluency, flexibility } \\
\text { (Module), originality } \\
\text { (Module) }\end{array}$ & $2 \mathrm{~h} .50 \mathrm{~min}$ \\
\hline $\begin{array}{l}\text { Task } 5 \text { - } \\
\text { Fifth } \\
\text { Lesson }\end{array}$ & $\begin{array}{l}\text { The robot } \\
\text { development } \\
\text { project using } \\
\text { Lego } \\
\text { Mindstorms } \\
\text { Track3r Tank } \\
\text { Bot }\end{array}$ & $\begin{array}{l}\text { Audio, } \\
\text { video, } \\
\text { robot, } \\
\text { Module }\end{array}$ & $\begin{array}{l}\text { Visualization, } \\
\text { imagination, } \\
\text { modifying, extending, } \\
\text { concretizing, making } \\
\text { stories, negation give } \\
\text { stimulation for } \\
\text { fluency, flexibility, } \\
\text { elaboration, originality }\end{array}$ & 3h. $20 \mathrm{~min}$ \\
\hline $\begin{array}{l}\text { Task } 6 \text { - } \\
\text { Sixth } \\
\text { Lesson }\end{array}$ & $\begin{array}{l}\text { The robot } \\
\text { development } \\
\text { project using } \\
\text { Lego } \\
\text { Mindstorms } \\
\text { Ev3rstorm } \\
\text { Humanoid } \\
\text { Bot }\end{array}$ & $\begin{array}{l}\text { Audio, } \\
\text { video, } \\
\text { robot, } \\
\text { Module }\end{array}$ & $\begin{array}{l}\text { Visualization, } \\
\text { imagination, } \\
\text { modifying, extending, } \\
\text { concretizing, making } \\
\text { stories, negation give } \\
\text { stimulation for } \\
\text { fluency, flexibility, } \\
\text { elaboration, } \\
\text { originality }\end{array}$ & 3h. $30 \mathrm{~min}$ \\
\hline $\begin{array}{l}\text { Task } 7 \text { - } \\
\text { Seventh } \\
\text { Lesson }\end{array}$ & $\begin{array}{l}\text { The robot } \\
\text { development } \\
\text { project using } \\
\text { Humanoid } \\
\text { Robot. }\end{array}$ & $\begin{array}{l}\text { Audio, } \\
\text { video, } \\
\text { robot, } \\
\text { Module }\end{array}$ & $\begin{array}{l}\text { Visualization, } \\
\text { imagination, making } \\
\text { stories give } \\
\text { stimulation for fluency }\end{array}$ & 3h. $30 \mathrm{~min}$ \\
\hline
\end{tabular}

Task 2. After the introduction of the component, in the second meeting, the robot development project commenced. The students got new experiences with the robotic lesson using arm robot. Thus, the purpose of this activity is to provide knowledge to the students about static robot, one that 
resembles the work of a human arm. Students will understand the motion of the robot system and also how to control the robot arm and its application. The activity is shown in Fig. 4.

Task 3. The students got some experiences from the mobile robot, this lesson was aimed at providing knowledge to the students about a robot that can move. Hence, the students can be able to distinguish between mechanical, actuator and control system in static and mobile robots. The activity is shown in Fig. 5.

Task 4. The students were introduced to the drone, this lesson aimed at providing knowledge to the students that the robot can fly. The Students can find out the mechanical, actuator and control system on the type of a flying robot. The activity is shown in Fig. 6.

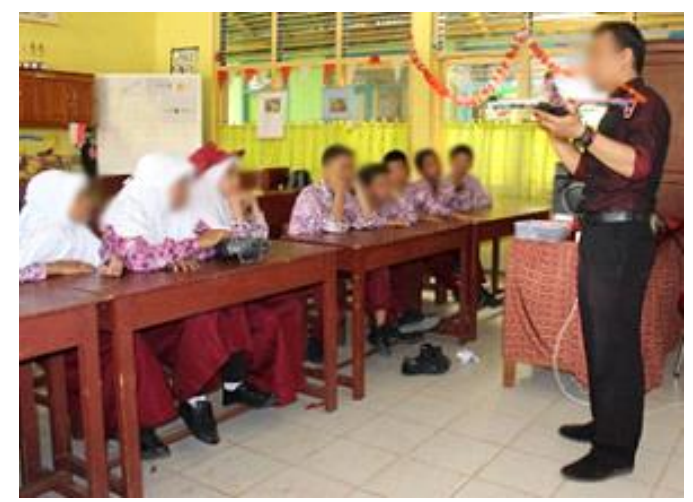

Fig. 3. The Students were Introduced to Several Types of Robots, Such as Robot with Wheels, Robot with Legs, Robot Like a Human.

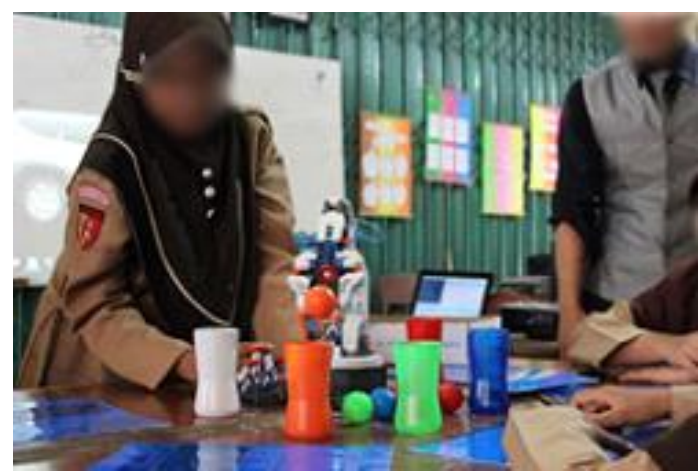

Fig. 4. The Students Get a New Experience with a Robotic Lesson using Arm Robot.

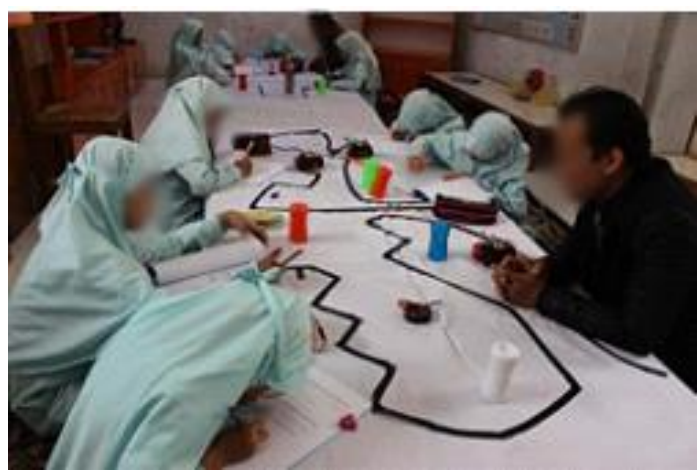

Fig. 5. Students Distinguish Mechanical, Actuator and Control System in Static Robots and Mobile Robot.

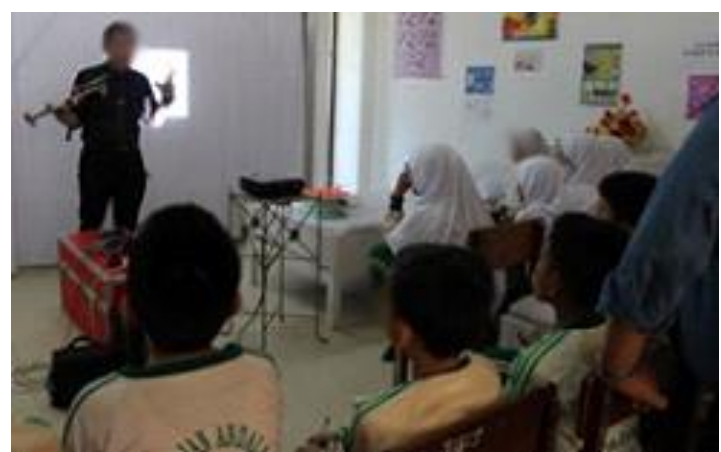

Fig. 6. The Students find out the Mechanical, Actuator and Control System on the Type of a Flying Robot.

Task 5. The students got some experience with Lego Mindstorms. Lego Mindstorms is an assembly kit that contains building block pieces (construction kits) and a programmable control unit that can enable one to build a number of robots [19], [20], [21]. This kit includes all the important components needed to build a robot, such as connectors, axle, busing, beams, frames, tubes, gears, belts, shafts, wheel, motors, sensors, and control center.

Control center in Lego Mindstorms is the Brick. The Brick can send a programme to the motors, receive information from sensors, among other functions. Additionally, the Lego Mindstorms consist of a large motor and a medium one as an actuator. It also comprises of different sensors: the color sensor, ultrasonic sensor, touch sensor, infrared sensor, gyro sensor, and the temperature sensor. This description was accompanied by displaying each of the components. The projects achieved by the students were, the making of a tracker tank bot, as the students were adequately taught on how to design, construct, build and control a tracker tank bot. The activity is shown in Fig. 7.

Task 6. The students also use Lego Mindstorms to make a Humanoid Bot. Students are able to know the differences between humanoid robots and other types of robots. The most important thing was that students can understand that Lego Mindstorms can form several types of robots, so students can develop their imagination to be able to create other types of robots. The activity is shown in Fig. 8.

Task 7. The students can also test platforms different from the original robot, the students were encouraged to use their imagination, and they were also introduced to control the robot with a smartphone, the robot used is the alpha robots.

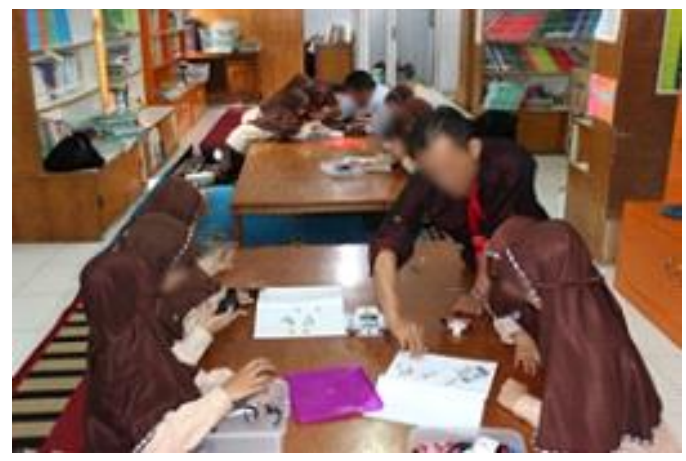

Fig. 7. The Students Get Experience with Lego Mindstorms. 


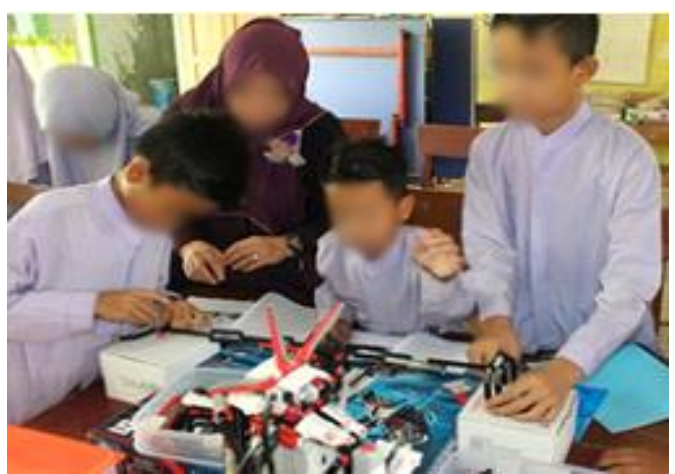

Fig. 8. Sample of Circular Pattern.

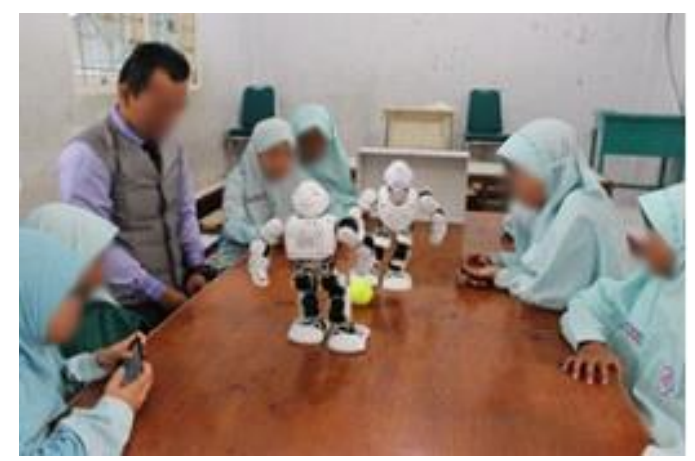

Fig. 9. The Students can Also Test Platforms different from the Original Robot.

After having conducting seven tasks, the process proceeded with the post-test in the control class. Also, the experimental class is expected from the intervention, this is so because 7 tasks in the classroom experiments can actually produce the post-test scores of the experimental class, which is much better than the control class. The activity is shown in Fig. 9.

\section{F. Post-Test}

Post-test is a measurement of the level of the figural creativity of students after getting intervention. After the intervention of the robotics technology was completed, the figural creativity of the students was measured by TKF (Posttest). Thus, Post-test needs to be done in order to determine the extent of the increase in the figural creativity of the student. The pencil and paper tests were completed individually in a group administered session. The figural creativity test in the post-test had the same activities as that of the pre-test. The total score were then translated to the standard value and the number of raw values becomes the creative quotient score, which was then translated into figural creativity levels.

\section{RESULTS}

The case study was carried out on the elementary school with KTSP curriculum (Team A) and K-13 Curriculum (Team B). To analyze the results of the figural creativity test in pretest and post-test, statistical analyses were conducted by using the Statistical Product and Service Solutions Software, and the data analysis is being divided into two parts.

\section{A. Paired Sample T Test for Team A}

The first part was the paired sample t-test, this analysis aimed to find out how significant the differences in the figural creativity of students were before the intervention and after the intervention. The first analysis is carried out on students with the KTSP curriculum.

H0: There are no differences in the mean values between the pre-test to the post-test of Team A, which means no intervention effects in improving the students' figural creativity.

Ha: There are differences in the mean values between the pre-test to the post-test of Team A, which means there are significant effects of intervention to improving the students' figural creativity.

Guidelines for decision making in paired sample $t$ test analysis are based on significance values (sig) with the following provisions: if sig. (2-tailed) value $<0.05$, it means that $\mathrm{HO}$ is rejected and $\mathrm{Ha}$ is accepted, and then if sig. (2-tailed) value $>0.05$, it means $\mathrm{H} 0$ is accepted and $\mathrm{Ha}$ is rejected.

Table IV shows the sig (2-tailed) value in team $\mathrm{A}=.572 \mathrm{P}>$ .05 ; hence it can be concluded that there were no significant differences in the mean value of the figural creativity for the pre-test with the post-test, thus $\mathrm{HO}$ is accepted and $\mathrm{Ha}$ is rejected. Paired differences mean $=-1.7$, these values show the difference between the mean value of pre-test $(M=99.35)$ with the mean value of the post-test $(M=101.05)$, the descriptive statistics is shown in Table V.

Based on the result of the figural creativity test in the pretest and post-test for team A (KTSP curriculum), the student's scores were converted to figural creativity levels, thus the number of students found for each level of creativity in team A is shown in Table VI and Fig. 10.

TABLE. IV. PAIRED SAMPLES TEST FOR KTSP ElEMENTARY SCHOOL

\begin{tabular}{|c|c|c|c|c|c|}
\hline \multirow[b]{2}{*}{ Team } & \multicolumn{2}{|c|}{ Paired Differences } & \multirow[b]{2}{*}{$\mathbf{t}$} & \multirow[b]{2}{*}{ df } & \multirow[b]{2}{*}{$\begin{array}{l}\text { Sig. (2- } \\
\text { tailed) }\end{array}$} \\
\hline & Mean & $\begin{array}{l}\text { Std. } \\
\text { Deviation }\end{array}$ & & & \\
\hline $\begin{array}{l}\text { Pre-test team A - } \\
\text { Post-test team A }\end{array}$ & -1.7 & 13.227 & -0.575 & 19 & 0.572 \\
\hline
\end{tabular}

TABLE. V. DESCRIPTIVE Statistics In KTSP ElEMENTARY SCHOOL STUDENTS

\begin{tabular}{|l|l|l|l|l|l|l|l|l|}
\hline \multirow{2}{*}{$\begin{array}{l}\text { Tea } \\
\text { m }\end{array}$} & \multicolumn{4}{|l|}{ Pre-Test } & \multicolumn{4}{l|}{ Post-Test } \\
\cline { 2 - 9 } & $\begin{array}{l}\mathrm{ni} \\
\mathrm{x}\end{array}$ & $\begin{array}{l}\text { Mea } \\
\mathrm{n}\end{array}$ & $\begin{array}{l}\text { Std. } \\
\text { Deviation }\end{array}$ & $\begin{array}{l}\text { Mi } \\
\mathrm{n}\end{array}$ & $\begin{array}{l}\text { Ma } \\
\mathrm{x}\end{array}$ & Mean & $\begin{array}{l}\text { Std. } \\
\text { Deviation }\end{array}$ \\
\hline $\mathrm{A}$ & 87 & 120 & $\begin{array}{l}99.3 \\
5\end{array}$ & 10.535 & 87 & 130 & $\begin{array}{l}101.0 \\
5\end{array}$ & 11.124 \\
\hline
\end{tabular}

TABLE. VI. Pre-Test And Post-Test TKF LeVel in Team A (KTSP CURRICULUM)

\begin{tabular}{|l|l|l|}
\hline \multirow{2}{*}{ TKF Level } & \multicolumn{2}{|l|}{ Team A (Experimental Group) } \\
\cline { 2 - 3 } & Pre-Test TKF & Post- Test TKF \\
\hline Superior & 1 & 1 \\
\hline High Average & 4 & 3 \\
\hline Average & 9 & 10 \\
\hline Low Average & 6 & 6 \\
\hline & 20 & 20 \\
\hline
\end{tabular}




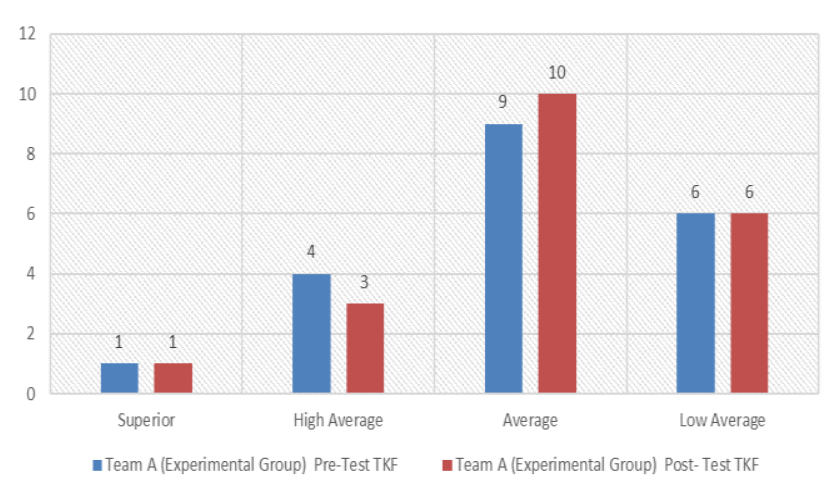

Fig. 10. Pre-Test and Post-Test TKF Level in Team A (KTSP Curriculum).

According to Table VI, the students in team A $(\mathrm{N}=20)$ consist of: superior level $=1$ in pre-test and post-test, high average level $=4$ students (pre-test) and 3 students (post-test), average level $=9$ students (pre-test) and 10 students (post-test), low average level $=6$ students in pre-test and post-test.

\section{B. Paired Sample T Test for Team B}

The second analysis was carried out on students in team B ( $\mathrm{K}-13$ curriculum). The following hypothesis is stipulated:

H0: There are no differences in the mean values between the pre-test to post-test of Team B, which means there are no intervention effects in improving students' figural creativity.

Ha: There are differences in the mean values between the pre-test to post-test of Team B, which means there are significant effects of intervention to improving students' figural creativity.

Table VII shows the sig (2-tailed) value in team $\mathrm{B}=.000$ $\mathrm{P}<.05$, so there were significantly different between the mean values of students' creativity before (pre-test) and after (posttest) the intervention, thus $\mathrm{HO}$ is rejected and $\mathrm{Ha}$ is accepted. Paired differences mean $=-21.85$, these values show the difference between the mean value of pre-test $(M=116.80)$, the descriptive statistics is shown in Table VIII.

Based on the result of figural creativity test in the pre-test and post-test for team B (K-13 curriculum), the student's scores were converted to figural creativity levels, thus the number of students found for each level of creativity in team B is shown in Table IX and Fig. 11.

According to Table VIII, the students in team $B(N=20)$ consist of: no student has figural creativity superior level in the pre-test but in the post-test, there were 9 students that had the figural creativity superior level; high average level $=1$ student in the pre-test, and 6 students in the post-test; average level = 13 students in pre-test, and 5 students in the post-test; low average level $=6$ students in pre-test and no student in the post-test; however, no student had low figural creativity level in both tests.

The next analysis was conducted on the mean value of students who received the intervention, this analysis aims to know the amount of the enhancement of figural creativity that is existent in each team (team A with team B)?
TABLE. VII. PAIRED SAMPLES TEST FOR KTSP ELEMENTARY SCHOOL

\begin{tabular}{|c|c|c|c|c|c|}
\hline \multirow{2}{*}{ Team } & \multicolumn{2}{|c|}{ Paired Differences } & \multirow{2}{*}{$\mathbf{t}$} & \multirow{2}{*}{ df } & \multirow{2}{*}{$\begin{array}{l}\text { Sig. }(2 \\
\text { tailed) }\end{array}$} \\
\hline & Mean & Std. Deviation & & & \\
\hline $\begin{array}{l}\text { Pre-test team B- } \\
\text { Post-test team B }\end{array}$ & -21.85 & 8.804 & -11.1 & 19 & 0.000 \\
\hline
\end{tabular}

TABLE. VIII. DESCRIPTIVE STATISTICS IN K-13 ElemEnTARy SCHOOL STUDENTS

\begin{tabular}{|c|c|c|c|c|c|c|c|c|}
\hline \multirow{2}{*}{$\begin{array}{l}\text { Tea } \\
\text { m }\end{array}$} & \multicolumn{4}{|c|}{ Pre-Test } & \multicolumn{4}{|c|}{ Post-Test } \\
\hline & $\begin{array}{l}\mathrm{Mi} \\
\mathrm{n}\end{array}$ & $\begin{array}{l}\text { Ma } \\
\mathrm{x}\end{array}$ & $\begin{array}{l}\text { Mea } \\
\mathrm{n}\end{array}$ & $\begin{array}{l}\text { Std. } \\
\text { Deviation }\end{array}$ & $\begin{array}{l}\mathrm{Mi} \\
\mathrm{n}\end{array}$ & $\begin{array}{l}\text { Ma } \\
\mathrm{x}\end{array}$ & $\begin{array}{l}\text { Mea } \\
n\end{array}$ & $\begin{array}{l}\text { Std. } \\
\text { Deviation }\end{array}$ \\
\hline B & 85 & $\begin{array}{l}11 \\
3\end{array}$ & $\begin{array}{l}94.9 \\
5\end{array}$ & 7.584 & $\begin{array}{l}10 \\
0\end{array}$ & $\begin{array}{l}13 \\
3\end{array}$ & $\begin{array}{l}116 . \\
80\end{array}$ & 8.776 \\
\hline
\end{tabular}

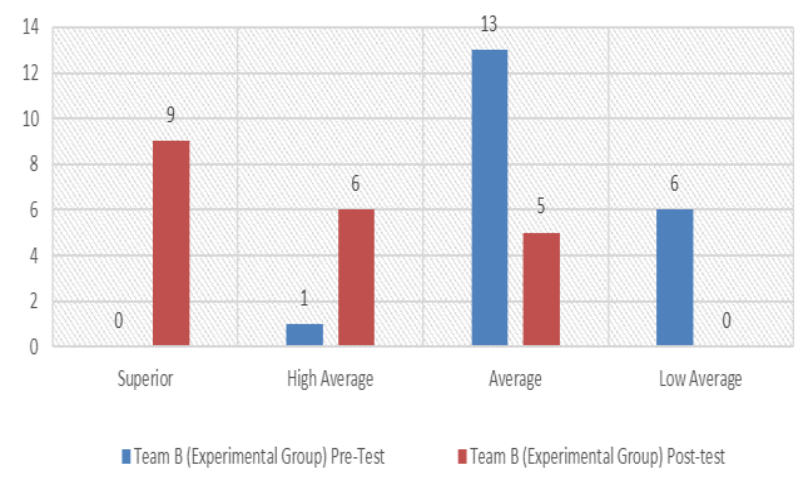

Fig. 11. Pre-Test and Post-Test TKF Level in Team B (K13 Curriculum).

The enhancement mean posttest of figural creativity $(\overline{X 1})$ against the mean pretest $(\overline{X 2})$ of figural creativity could be known by calculating the value of $P .(P(\%)=((\overline{X 1}-\overline{X 2}) / \overline{X 2}) x$ 100\%) [27].

$P$ of Team $\mathrm{A}=\underline{101.05-99.35} x 100 \%$

99.35

$$
=1.7 \%
$$

$P$ of Team B $=\underline{116.80-94.95} x 100 \%$

$$
\begin{aligned}
& 94.95 \\
& =23 \%
\end{aligned}
$$

The figural creativity of student's team A after getting the intervention of robotic technology were increased to $1.7 \%$, while the figural creativity of student's team B after getting the intervention of robotic technology were increased up to $23 \%$.

Based on Table $\mathrm{X}$, in team A the changes in the number of students at each level of creativity in the pretest and posttest did not have a significant change, while in team B there were significant changes at each level, also in the pretest no student attained a creativity level superior level, but in the post-test there were 9 students; in the pretest only 1 student had a high average score, however in the post-test, there was an increase of up to6 students. Very interestingly, at the low average level, in the pretest there were 6 students that had low average of figural creativity, but in the post-test, the creativity decreased after the no-student intervention had a low figural creativity level. 
TABLE. IX. Pre-Test and Post-Test TKF LeVel in Team B (K13 CURRICULUM)

\begin{tabular}{|l|l|l|}
\hline \multirow{2}{*}{ TKF Level } & \multicolumn{2}{|c|}{ Team B (Experimental Group) } \\
\cline { 2 - 3 } & Pre-Test & Post-test \\
\hline Superior & 0 & 9 \\
\hline High Average & 1 & 6 \\
\hline Average & 13 & 5 \\
\hline Low Average & 6 & 0 \\
\hline & 20 & 20 \\
\hline
\end{tabular}

TABLE. X. Figural CREativity LeVel of Team A and Team B

\begin{tabular}{|l|l|l|l|l|}
\hline \multirow{2}{*}{ TKF Level } & \multicolumn{2}{|l|}{$\begin{array}{l}\text { Team A (KTSP- } \\
\text { Experimental Group) }\end{array}$} & \multicolumn{2}{l|}{$\begin{array}{l}\text { Team B (K13- } \\
\text { Experimental Group) }\end{array}$} \\
\cline { 2 - 5 } & $\begin{array}{l}\text { Pre-Test } \\
\text { TKF }\end{array}$ & $\begin{array}{l}\text { Post Test } \\
\text { TKF }\end{array}$ & $\begin{array}{l}\text { Pre-Test } \\
\text { TKF }\end{array}$ & $\begin{array}{l}\text { Post Test } \\
\text { TKF }\end{array}$ \\
\hline Superior & 1 & 1 & 0 & 9 \\
\hline High Average & 4 & 3 & 1 & 6 \\
\hline Average & 9 & 10 & 13 & 5 \\
\hline Low Average & 6 & 6 & 6 & 0 \\
\hline & 20 & 20 & 20 & 20 \\
\hline
\end{tabular}

\section{DISCUSSION}

Figural creativity is a very important skill possessed by students in the workplace of the $21^{\text {st }}$ century, and the very interesting thing is that creativity skill can be developed by learning process, training, etc.[1].

The first finding of this study was by integrating robotic technology in learning activities; it has been proven to improve Figural creativity. The robotic technology learning is effective to improve figural creativity of students, this is consistent with several studies that have been done before, robotics is one way of fun learning which can make students think more creatively in creating something new [2]. Thus, robot can be used by children as a tool to boost new ideas and stimulate their creativity [3], also the potential of educational robotics has been acknowledged earlier, in particular with the potential to facilitate curiosity and creativity [4].

The second finding is that it is appropriate to apply robotic technology in the latest curriculum, namely the K-13 curriculum, based on the results of the figural creativity data analysis, which is much more improved for students with curriculum K-13; thus the use of robotic technology can support the purpose of K-13 curriculum learning process, which is to produce graduates who have creativity skills [5].

Therefore, we suggest that robotic technology as an educational tool can be applied in the educational sectors. This suggestion is consistent with De Zhang (2013) which strongly promotes robot innovative education, the educational reform, as well as promote the further development of robot technology [6]. Other suggestion is that, Robotic technology can be aligned with the students' curriculum, due to the fact that robotic project have showed a great upgrade in the children's education, in particular to develop general skills necessary in their life [7].

\section{CONCLUSION}

This study investigated the effect of applying technology in the enhancement of figural creativity between students with K13 curriculum and KTSP curriculum after intervening with them. To find out the initial level of the students' creativity, pretest was conducted for all participants. Researching the influence of technological intervention will provide suggestions regarding the development of student learning processes in schools to enhancement Figural Creativity skills. Based on the results of measuring the figural creativity of students from team $\mathrm{A}$ and $\mathrm{B}$, there were unequal results from each team, which were from different experimental groups. This shows that the intervention of robotics technology in students with different curricula will result in creativity based on different improvements, especially the enhancement of the figural creativity skill of the students (see Table X).

Lesson one to seven is designed and arranged with good calculations, so students easily understand and are not burdened with something new. The lessons commenced with static robots to dynamic robots that can be controlled using a remote, even controlled using a smartphone. The material provided was arranged from the simplest to the higher technology. The robots used have various forms, colors, and functions that make students interested in learning and give them new knowledge and experience; with this, the students are able to discover or create new things in the field of technology in the future. This material follows the technological trends in the industrial revolution 4.0 era, so students will not be awkward with the technological advancements that exist. Lesson one to seven is packaged and delivered as seen in task 1 to task 7, intervention is done in 7 meetings. This material is delivered in audio, visual and kinesthetic forms, which is able to stimulate the four components of figural creativity, namely: originality, fluency, flexibility, and elaboration. The effect of this intervention is the figural creativity enhancement of the students.

Robotic technology can be an innovative educational tool that provides a positive effect on the development of the skill of students. Students who get the intervention (experimental group) have increased in their figural creativity better than students who did not get the intervention (control group). Based on statistical mean values of the figural creativity, the $\mathrm{K} 13$ curriculum in the experimental group achieved greater mean values of figural creativity than those in the KTSP curriculum, it can be concluded that robotic technology learning is more effective in enhancing the figural creativity in students with the K13 curriculum.

\section{ACKNOWLEDGMENT}

This research was supported by LLDIKTI from The Ministry of Research and Technology, which funded this research through the "Penelitian Strategis Nasional Institusi (PSNI)" program. We would also like to thank all participants for their time spent in this research.

\section{REFERENCES}

[1] E.Afari, \& M. S. Khine, "Robotics as an Educational Tool: Impact of Lego Mindstorms", International Journal of Information and Education Technology, pp. 437-442, 2017. 
[2] P. Alves-Oliveira, P. Arriaga, A. Paiva, and G. Hoffman, "YOLO, a Robot for Creativity," no. June, pp. 423-429, 2017.

[3] N. Anderson, \& K. Potočnik, "Innovation and Creativity in Organizations: A State-of-the-Science Review," Prospective Commentary, and Guiding Framework. Journal of Management, vol. 40, no. 5, 1297-1333, 2014.

[4] J. E. Baek, "Effects of Robot-Based Learning on Learners ' Creativity," Education, vol. 127, pp. 130-134, 2016.

[5] B. Barbot, M. Besançon, \& T. Lubart, "Creative potential in educational settings: its nature, measure, and nurture," Education 3-13, vol. 43, no. 4, pp. 371-381, 2015.

[6] F. Basoeki, F. D. Libera, E. Menegatti, \& M. Moro, "Robots in education: New trends and challenges from the Japanese market," Themes in Science \& Technology Education, vol. 6, no. 1, pp. 51-62, 2013.

[7] F. B. V. Benitti, "Exploring the educational potential of robotics in schools: A systematic review," Computers and Education, vol. 58, no.3, pp. 978-988, 2012.

[8] B. Hendrik, N. M. Ali, R. Sulaiman, M. Masril, and H. T. Fikri, "Intellectual Intelligence Analysis on Figural Creativity Levels for Elementary School Students," In Digital Transformation Landscape in the Fourth Industrial Revolution (4IR) Era pp. 167-176, 2018.

[9] D. T. Burhans and K. Dantu, " $\{$ ARTY: $\}$ Fueling Creativity through Art, Robotics and Technology for Youth,” Aaai, pp. 4765-4770, 2017.

[10] H. Casakin, \& S. Kreitler, "Evaluating Creativity in Design Problem Solving," Design Research Society, January 2014.

[11] T. Cassia, De, N. Pontifícia, U. Católica, \& S. Paulo, "Intelligence and Creativity: Relationships and their Implications for Positive Psychology," Psico-USF, Bragança Paulista, vol. 20, no. 2, pp. 195-206, 2015.

[12] B. Cavaş, \& T. Kesercioğlu, "The effects of robotics club on the students' performance on science process \& scientific creativity skills and perceptions on robots, human and society," In 3rd International Workshop, Teaching Robotics, Teaching with Robotics, pp. 40-50, 2012.

[13] J. Chetty, "Lego@mindstorms: Merely a toy or a powerful pedagogical tool for learning computer programming?," Conferences in Research and Practice in Information Technology Series, vol. 159, pp. 111-118, January 2015.

[14] M. Fadly, "Increased CNC Learning Results," Universitas Negeri Semarang, 2015.
[15] M. Garaigordobil, "Intervention in Creativity With Children Aged 10 and 11 Years: Impact of a Play Program on Verbal and Graphic Figural Creativity," vol.18, no. 3, pp. 329-345, 2006.

[16] M. Garaigordobil and L. Berrueco, "Effects of a Play Program on Creative Thinking of Preschool Children," Span. J. Psychol., vol. 14, no. 02, pp. 608-618, 2011.

[17] L. Hakim, “Analisis Perbedaan Antara Kurikulum," vol. 17, no. 2, pp. 280-292, 2017.

[18] B. Hendrik, N. M. Ali, R. Sulaiman, M. Masril, and H. T. Fikri, "The Effect Of Curriculum On The Level Of Figural Creativity Among Elementary School Students," Journal of Built Environment, Technology and Engineering, vol. 4, no. 11, pp. 200-205, 2018.

[19] S. Humble, P. Dixon, \& E. Mpofu, "Factor structure of the Torrance Tests of Creative Thinking Figural Form A in Kiswahili speaking children: Multidimensionality and influences on creative behavior," Thinking Skills and Creativity, vol.27, pp. 33-44, 2018.

[20] R. Mangiwa, "Ability of Intelligence Quotient (IQ) Faculty of Medicine Students General Medicine Study Program," Jurnal E-Biomedik (EBM), vol. 2, no. 3, 2014.

[21] N. J. Marzieh Arefi, "Comparation of Creativity Dimensions (Fluency, Flexibility, Elaboration, Originality) between Bilingual Elementary Students (Azari language-Kurdish language) in Urmia City - Iran," The IAFOR International Conference on Language Learning, 2016.

[22] Sugito, Problems of Creativity And Measurement, Fakultas Bahasa dan Seni Universitas Negeri Medan, 1996.

[23] R., T. Herman, \& J. A. Dahlan, "The Enhancement of Students' Critical Thinking Skills in Mathematics through The 5E Learning Cycle with Metacognitive Technique," IJER, vol. 4, no. 7, pp. 347-360, 2017.

[24] E. M. Nurhadi Santoso, "Pengembangan Kreativitas Siswa Berdasarkan Implementasi Kurikulum 2013,” Pedagogik, vol. 2, pp. 19-25, 2014.

[25] A. A. Potur, \& O. Barkul, "Gender and creative thinking in education: A theoretical and experimental overview," A|Z ITU Journal of Faculty of Architecture, vol. 6, no. 2, pp. 44-57, 2009.

[26] J. P. Rushton, "Performance on Raven' $s$ Matrices by African and White University Students in South Africa," vol. 28, no. 4, pp. 251-265, 2000.

[27] A. Vinsentricia, S. Sudarisman, \& J. Ariyanto, "Efforts To Improve Students Figural Creativity Through the Use of 5E Learning Cycle With Interrelationship Diagram on Review," Pendidikan Biologi, vol. 7, no. 3, pp. 27-36, 2015. 